\title{
SUMMARY OF TABLES AND GRAPHS
}

0. Main indicators and population

1. Main in dicators for the CMEA region .......... 32

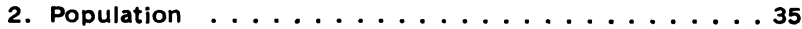

1. Production: Sources and Distribution

0. Definitions .................... 43

1. National product ..................... 45

2. Employment and wages by economic sectors . . . . . . 57

3. Gross investment and gross fixed assets by

economic sectors . . . . . . . . . . . . 111

4. Industrial sector .................. 140

5. Agriculture ................... 254

11. Consumption and the Standard of Living

0. Definitions ................... 297

1. Consumption and retail trade turnover . . . . . . 298

2. Incomes and prices . . . . . . . . . . . . . . 304

3. Per capita consumption of staple foods and beverages . . 309

4. Socio-economic indicators ........... 315

111. Foreign Trade

0. Definitions and conversion factors ........... 321

1. Exports of CMEA countries . . . . . . . . . 325

2. Imports of CMEA countries ............. 331

3. Exports and imports of CMEA countries

by regions . . . . . . . . . . . . . . 337

4. Exports and imports of CMEA countries

by commodity groups . . . . . . . . . . . . 365

5. CMEA foreign trade with the industrial West ..... 386

IV. Finance

0. Definitions ........................ 393

1. State revenue and expenditure ... . . . . . . . 394

2. Credits to enterprises, institutions and

private households ............... 414

3. Private savings deposits .............. . . 418

4. Money in circulation ................ 420

V. Energy

0. Conversion factors ................. . 423

1. Resources and consumption ... . . . . . . . 424

2. Production in natural units ............. 429

3. Production, net imports and consumption ...... . 436

4. Imports and exports in natural units .......... 445

5. Western energy imports from CMEA .......... 462

6. Western energy exports to CMEA ........... 468 